Научная статья

УДК $811.512 .31 ’ 36$

DOI: $10.18101 / 2305-459 X-2020-4-79-85$

\title{
ОТФРАЗЕОЛОГИЧЕСКОЕ СЛОВООБРАЗОВАНИЕ В БУРЯТСКОМ ЯЗЫКЕ
}

(C) Харанутова Дарима Шагдуровна доктор филологических наук, доцент, Бурятский государственный университет им. Доржи Банзарова Россия, 670000, г. Улан-Удэ, ул. Ранжурова, 6 dkharanutova@mail.ru

\author{
(C) Николаева Арюна Цырендондоковна \\ аспирант, \\ Бурятский государственный университет им. Доржи Банзарова \\ Россия, 670000, г. Улан-Удэ, ул. Ранжурова, 6 \\ ryuna1810@rambler.ru
}

Аннотация. Работа посвящена проблеме отфразеологического словообразования в бурятском языке. В работе изложено понимание авторов теоретической проблематики словообразования, в основе которого лежат межуровневые связи. На материале употребительных слов бурятского языка, являющихся результатом взаимодействия фразеологического и лексического уровней, узуальность которых подкреплена лексикографически, исследуются словообразовательное соотношение и мотивированность соотносительных фразеологических единиц и образованных слов. Описываются межуровневые омонимичные отношения, когда от фразеологизма образуется слово с тождественным компонентным составом с номинативно цельным значением. Подчеркивается, что в образовании отфразеологических слов немаловажную роль играет импликация. Раскрывается роль семантических центров в фразеологических единицах и их роль в образовании производных лексем. Выявляются некоторые особенности образования отфразеологических слов в бурятском языке, связанные со структурой и семантикой производящего фразеологизма.

Ключевые слова: отфраземная деривация; отфразеологическое словообразование; отфразеологические дериваты; семантический центр; импликация; омонимичные межуровневые связи.

\section{Для цитирования}

Харанутова Д. Ш., Николаева А. Ц. Отфразеологическое словообразование в бурятском языке // Вестник Бурятского государственного университета. Язык. Литература. Культура. 2020. Вып. 4. С. 79-85.

Одним из способов пополнения лексики бурятского языка является отфразеологическое образование дериватов. Нельзя утверждать, что данный процесс регулярен, но он закономерен. Фразеологические единицы (ФЕ), являясь продуктом творчества, в свою очередь, сами спешат дать жизнь дериватам и пополняют не только фразеологический фонд языка, но и лексический. 
Образование новых единиц от фразеологизмов понимается как отфразеологическая деривация, которая идет в двух направлениях: основной процесс рождения фразеологической единицы от фразеологизмов определяется как деривация в сфере фразеологии $[6$, с. 58], второй же процесс предполагает взаимодействие двух уровней: фразеологического и лексического, когда производящим - для слов являются фразеологизмы.

По поводу наименования процесса образования слов от фразеологизмов предлагаются разные термины: лексикализация словосочетания (Р. Н. Попов) [7], отфраземное словообразование (Е. В. Сенько) [8], семантическое сжатие (Т. Н. Семенова) [9], отфразеологическое словообразование (О. И. Литвинникова) [1] и др. На наш взгляд, термин отфразеологическое словообразование наиболее точен, так как в нем содержится понимание межуровневого процесса образования слов, отличного от традиционного словообразования, семантически близки ему термины отфраземное словообразование и отфразеологическое словопроизводство.

В отношении имеющихся наименований лексем, образованных от фразеологизмов, заметим, что все они синонимичны и потому взаимозаменяемы: omфразеологические лексемы, отфраземные слова, отфразеологические дериваты, отфразеологические слова и сложный термин слова, образованные на базе фразеологизмов. В качестве рабочего мы принимаем термин отфразеологические слова, так как он наиболее близок к пониманию отфразеологического словообразования.

Под отфразеологическими словами понимается узуальная речевая лексическая единица, образованная на базе фразеологизмов [6, с. 264].

Несмотря на несложившуюся единую точку зрения на само языковое явление, на неустоявшийся понятийный аппарат и специфичность его проявления в разных языках, не вызывает сомнения тот факт, что отфразеологическое словообразование носит в языке системный и регулярный характер.

В данной работе уделяется внимание отфразеологическим словам бурятского языка, узуальность которых закреплена лексикографически.

Следует отметить, что в бурятском языке существует массив слов, где словообразовательное соотношение и мотивированность соотносительных фразеологических единиц и их производных самоочевидны. Продемонстрируем прозрачные межъязыковые деривационные связи производных слов на материале Словаря-справочника фразеологизмов Т. Б. Тагаровой [11] и Бурятско-русского словаря [3; 4]: бэеэ хүсэхэ `букв. тело свое догнать. Созреть ' [11, c. 60], (достигший возраста) $\rightarrow$ бэеэ хүсэһэн (хүн) 'прил. сост. взрослый [3, с. 170]; бэеэ үгэхэ 'отдать себя ' $[11$, с. 59] $\rightarrow$ бэеэ үгэнги 'прил. сост. самоотверженный, преданный` [3, с. 170]; хара һанаан `Предосуд. букв. Черные помыслы. Плохие помыслы' $[11$, с. 299] $\rightarrow$ хара hанаатай 'зловредный, коварный $[4$, с. 398].

Однако имеющийся материал свидетельствует, что отфразеологическое словообразование в бурятском языке не всегда сопровождается прозрачной выводимостью соотносительных отношений производящего и производного, что 
зачастую приводит к неразличению производящего фразеологизма и отфразеологического слова: одна и та же языковая единица присутствует в толковом словаре как общеупотребительное слово, во фразеологическом словаре - как фразеологическая единица. Безусловно, это результат межуровневых омонимичных отношений, когда от фразеологизма образуется слово с тождественным компонентным составом с номинативно цельным значением.

Поясним сказанное на примерах, ФЕ амаа дэбтээхэ 'промочить горло, выпить немного спиртного ', амаа тамшааха 'рот свой облизывать, смаковать' [11, с. 21] (значение «причмокивать», на наш взгляд, точнее) в Бурятско-русском словаре квалифицируется как составные глаголы [3, с. 59]; фразеологизмы бэеэ бариха, бэеэ абаха $[11$, с. 58] в БРС трактуются как составные глаголы [3, с. 170]. Та же ситуация наблюдается и со словами гар табиха `букв. руку поставить, положить, подписаться', бэе муутай 'сост. прил. больной', бэе hайтай `сост. прил. здоровый' [3, с. 170].

Как видим, в этих примерах между производящим фразеологизмом и производным словом наблюдается семантическая и формальная тождественность. Явно проглядывается связь с использованием фразеологизмов в речи, а «особенности использования в речи влияют на их статус в языке» [5, с. 274]. Как пишет далее Е. Н. Ермакова, «фразеологизм, выступающий в роли производящей единицы, как правило, имеет внешний синоним - лексему в свободном употреблении» [5, с. 274], что и наблюдаем в этом случае: ФЕ бэе муутай `букв. человек с плохим телом. Человек с плохим здоровьем' - больной, ФЕ бэе hайтай `букв. человек с хорошим телом. Человек с хорошим здоровьем`- - доровый. Поэтому преобразование фразеологизма в слово в таких случаях не требует семантических и формальных изменений.

В отфразеологическом словообразовании наблюдается и другой механизм образования отфраземных слов, когда слово образуется от фразеологической единицы путем отсечения у него одного или более компонентов и наделения оставшегося компонента значением всего фразеологизма (импликация). Импликация, как пишет О. С. Ахманова, характеризуется тем, что «у слов, входящих в состав фразеологических единиц, возникают новые значения, сперва "потенциальные", как бы "поглощенные" суммарным значением сложного номинативного целого, но способные актуализироваться, выделиться, приобрести способность отдельного воспроизведения» [2, с. 170].

Способностью к вычленению из состава фразеологических единиц и употреблением в качестве самостоятельного неологизма обладают не все компоненты фразеологизма, а только те, которые образуют «семантический центр». Это может быть глагольный компонент, например в ФЕ гар табиха `букв. руку поставить, положить; подписаться семантический центр - табиха 'ставить, класть ' [4, с. 219], гартаа бариха (абаха) `в руках держать' - бариха `<...> 3. держать ' $[3$, с. 219]. В этих и подобных фразеологизмах семантическим центром является глагол, «на основе его значения складывается процессуальная семантика всей фразеологической единицы, он оформляет глагольными категориями ФЕ; компоненты прилагательное и существительное дополняют, конкретизируют семантику процессуальности» [10, с. 130]. 
В результате вычленения глагол-компонент обогащается значением всей фразеологической единицы, как в примере с процессуальным фразеологизмом амаа халаха `букв. рот разогреться. Быть навеселе, захмелеть' [11, с. 19], где основным семантическим центром является глагол халаха `греться, нагреваться, накаливаться; обжигаться, опаливаться' [4, с. 384]. Глагол халаха - семантический центр, имея внешние синонимы - глаголы захмелеть, выпить, вбирает в себя семантику фразеологической единицы и уже самостоятельно входит в словарный состав бурятского языка в этом значении.

Необходимо отметить, что образование новых слов способом импликации характерно не только для процессуальных фразеологизмов, но и для предметных и признаковых ФЕ, хотя следует признать, что в меньшей степени. Например, на базе фразеологизмов с компонентом аман `1. рот, уста, губы, пасть, зев (у животных), клюв (у птиц) язык; 2. перен. слово; язык, речь ` 3 , с. 59] рождаются дериваты, где семантический центр остается за существительным аман или же за определяемым его словом: ама задагай 'сост. прил. с распущенным языком` (точнее, болтливый), ама уран 'краснобай`, ама муута 'человек, говорящий только плохое (или неприятное), пессимист', ама hайтай 'говорящий только хорошее' [3, с. 59].

Другой пример, от фразеологизма гар хооһон 'с пустыми руками, без ничего; ничего не имеющий` способом импликации образуется прилагательное хооһон `пустой, с пустыми руками', например, хооһон арилха `отправляться ни с чем, уходить с пустыми руками '. В данном случае семантическим компонентом, который вобрал в себя значение ФЕ, является компонент хооһон, изначально имевший значение 'пустой, порожний' [4, с. 446]. Таким образом, перед нами слово, способное к самостоятельному употреблению в данном контексте и передающее смысл производящего фразеологизма «уйти ни с чем, с пустыми руками».

Языковой анализ отфразеологических слов бурятского языка (картотека насчитывает 250 слов) показывает, что процессуальные фразеологизмы служат производящей базой для новых слов гораздо чаще, нежели фразеологические единицы других семантико-грамматических классов.

Теперь резонно остановиться на вопросе формальной структуры производящего фразеологизма, играющего немаловажную роль в образовании новых слов. Базой для образования слов могут служить фразеологизмы с разным количеством компонентов, проиллюстрируем на примерах из словаря-справочника Т. Б. Тагаровой [11]:

двухкомпонентные: бэе муутай ‘букв. тело с плохим. Больной. прил.`, бэеэ абаха (холо боло юм) ‘бкв. тело свое взять. Держаться подальше, особняком’, бэеэ бариха ‘букв. тело свое держать. Сдержаться` и др.;

трехкомпонентные Бэеэ гарта бариха. 'Букв. Взять себя в руки. Сдержаться, собраться’, бэеэ дээгуур абаха `Букв. Тело свое поверху брать. Ставить себя выше других`;

четырехкомпонентные: бэе дээрээ даан абаха `укв. На тело свое брать. Взять ответственность на себя`; дарида гал хаяһан мэтэ `словно на порох огня подбросили, раздуть дело ; 
пятикомпонентные: Бэеэ хэхэ газараа оложо ядаха `букв. Тело свое положить места не найти, не быть в состоянии. Места себе не находить ', зосооһоo (сэдьхэлһээ) шулуу абажа хаяһан шэнги `букв. словно изнутри камень взяли и выбросили. На душе стало легко. Словно камень с души свалился. Испытывать облегчение, избавившись от чего- либо гнетущего, тягостного '.

Согласно нашим данным, из подвергшихся анализу 250 отфразеологических единиц $66 \%$ составляют слова, образованные на базе двухкомпонентных ФЕ, от трехкомпонентных фразеологизмов образовано 29\% слов, производные на базе четырехкомпонентных и пятикомпонентных единичны.

Словообразование на базе двухкомпонентных фразеологизмов чаще демонстрирует межуровневую омонимию: гар табиха 'букв. руку поставить, положить. Подписаться' [4, с. 219], нэрэеэ гутааха `опозорить имя свое. Опозориться`, нэрээ нэрлүүлхэ `прославить', нюдэндэ дулаахан 'симпатичный', толгойгоо заһаха 'опохмелиться'.

Лексемы, образованные от двухкомпонентных фразеологизмов, независимо от того, имплицируется ли производящий фразеологизм или нет, легко образуют дериваты аффиксальным способом и формируют словообразовательные гнезда: ср. бэедээ найдаха `надеяться на себя' $\rightarrow$ бэедээ найданги (хүн) 'самонадеянный (или самоуверенный) человек' $\rightarrow$ бэедээ найдангяар 'самоуверенно, самонадеянно ' $\rightarrow$ бэедээ найдалга 'самонадеянность'; халаха $\rightarrow$ халамги, халамгай 'прил. нетрезвый, подвыпивший', халамгайрха 'подвыпить, быть навеселе', халамгайшаг 'немного навеселе, слегка подвыпивший', халангы 'подвыпивший, навеселе', халангир `подогретый'(часто в разговорной речи используется в значении «подогретый изнутри, подвыпивший»), бага зэргэ халангы 'слегка подвыпивший' [3, с. 384], которые параллельно сосуществуют с образованными дериватами от неимплицированного ФЕ амаа халаха: ама халамгай ‘сост. прил. быть навеселе', ама халамгайшаг 'немного навеселе, слегка подвыпивший ’, ама халангы `навеселе, выпивший `ама бага халангир `подвыпивший, немного выпивший, под хмельком` [3, с. 384].

Справедливости ради надо отметить, что по численности отфразеологические словообразовательные гнезда не отличаются объемностью и обширностью, число дериватов в среднем колеблется возле цифры три, словообразовательные гнезда с неимплицированной вершиной, как ама халаха, единичны.

Среди трех-, четырех-, пятикомпонентных бурятских ФЕ межуровневые омонимичные отношения не наблюдаются, но они, как правило, имплицируются, при этом, заметим, число оставшихся компонентов варьируется. Примечательно, что уменьшение числа компонентов не зависит от структуры ФЕ. Сравним, трехкомпонентный ФЕ бэеэ гарта бариха сокращает только один компонент «гарта», и на основе имплицированного фразеологизма образуется глагол бэеэ бариха 'сдерживаться', и такой же трехкомпонентный ФЕ хормойдоо һалхи хабшуулха `бкв. в подоле ветер зажать, ветер в голове, быть ветреным, легкомысленным' [11, с. 317] или 'становиться легкомысленным, становиться вертопрахом (досл. загонять ветер себе в подол' [4, с. 449] оставляет только один компонент hалхи `ветер`, от которого образуется группа дериватов һалхирха ‘разгуливать, гу- 
лять', hалхирхаха '<..> 2. волочиться, повесничать (о людях)', hалхирхуу `волокита, повеса, гуляка ' 4 , с. 543]. Думаем, этот ряд необходимо пополнить прилагательным hалхитай 'легкомысленный (о человеке)', оно широко употребляется в разговорной речи носителей бурятского языка. В БРС это прилагательное дается как производное от существительного һалхи `ветер ` - hалхитай `1. ветреный (о погоде)' [4, с. 544].

Кстати, hалхи `ветер`, представляя в ФЕ грамматически зависимый компонент, актуализирует значение всего фразеологизма, так как является его семантическим центром. Оказывается, формальный компонентный состав фразеологических единиц, в принципе, не оказывает большого влияния на образование отфразеологических слов. Все дело, по-видимому, в семантическом центре ФЕ, в компоненте, актуализирующем значение всего фразеологизма.

Итак, фразеологизмы бурятского языка служат деривационной базой для образования производных слов, которые впоследствии приобретают статус узуальных лексем. Таким образом, они являются одним из источников пополнения лексического состава языка. Фразеологическая единица - производящее и слово, возникшее на базе фразеологизма, сосуществуют в языке как единицы разных уровней одного временного периода.

Между тем, несомненно, требуется дальнейшее исследование деривационного механизма бурятского отфразеологического словотворчества для понимания особенностей этого процесса.

\section{Литература}

1. Алексеенко М. А., Белоусова Т. П., Литвинникова О. И. Словарь отфразеологической лексики современного русского языка. М.: Азбуковник, 2003. 400 с.

2. Ахманова О. С. Очерки по общей и русской лексикологии. М., 1957. 295 с.

3. Шагдаров Л. Д., Черемисов К. М. Бурятско-русский словарь: в 2 т. Т. 1: А-Н. УланУдэ: Респ. тип., 2006. $636 \mathrm{c.}$

4. Шагдаров Л. Д., Черемисов К. М. Бурятско-русский словарь: в 2 т. Т. 2: О-Я. УланУдэ: Респ. тип., 2008. 708 с.

5. Ермакова Е. Н. Фразо- и словообразование в сфере фразеологии: дис. ... д-ра филол. наук. Тюмень, 2008. 430 c.

6. Ермакова Е. Н. Импликация как форма движения от фразеологизма к слову [Электронный ресурc]. URL: http://www.lib.csu.ru/vch/110/006.pdf (дата обращения: 10.09.2020).

7. Попов Р. Н. О взаимодействии в языке лексической и фразеологической систем (образование слов на базе фразем) // Проблемы образования фразеологических единиц. Тула, 1976. С. 15-28.

8. Сенько Е. В. Неологизация в современном русском языке конца XX века: межуровневый аспект: автореф. дис. ... д-ра филол. наук. Волгоград, 2000. 50 с.

9. Семенова Т. Н. К вопросу о явлении семантического сжатия во фразеологии // Вопросы семантики фразеологических единиц (на материале русского языка). Новгород, 1971. Ч. 12. С. 239-244.

10. Соловьева А. Д. Фразеологизм как мотивирующая единица // Проблемы лексической и словообразовательной мотивации в русском языке. Барнаул, 1986. С. 127-134.

11. Фразеологические единицы в языке бурятской прозы: словарь-справочник / сост. Т. Б. Тагарова. Иркутск: Иркут. ун-т, 2006. 420 с. 
PHRASEOLOGICAL WORD FORMATION IN THE BURYAT LANGUAGE

(C) Darima Sh. Kharanutova

Science doctor in Philology, Associate Professor,

Department of Russian Language and General Linguistics,

Institute of Philology, Foreign Languages and Mass Communications,

Banzarov Buryat State University

6, Ranzhurova St., Ulan-Ude, Russia 670000

dkharanutova@mail.ru.

(C) Aryuna Ts. Nikolaeva

Postgraduate student of the Department of Russian Language and General Linguistics,

Foreign Languages and Mass Communications,

Banzarov Buryat State University

ryuna1810@rambler.ru

Abstrakt. The work is devoted to the problem of phraseological word formation in the Buryat language. The article describes the authors' understanding of the theoretical problems of word formation, which is based on inter-level connections. On the basis of the used words of the Buryat language, which are the result of the interaction of phraseological and lexical levels, the usability of which is lexicographically supported, the wordformation ratio and motivation of correlative phraseological units and formed words are investigated. Interlevel homonymous relations are described, when a word is formed from a phraseological unit with an identical component composition with a nominative integral meaning. It is emphasized that implication plays an important role in the formation of phraseological words. The role of semantic centers in phraseological units and their role in the formation of derived lexemes are revealed. Some features of the formation of phraseological words in the Buryat language, associated with the structure and semantics of the generating phraseological unit, are revealed.

Keywords: phraseological derivation, phraseological word formation, phraseological derivatives, semantic center, implication, homonymous inter-level connections.

Статья поступила в редакцию 26.10.2020, одобрена после рецензирования 13.11.2020, принята к публикаџии 24.12.2020. 